the problem; rather, it is part of the problem, and the researcher is a participatory observer.

1. Torgerson D. Entre el conocimiento y la política: tres caras del análisis de políticas. In: Aguilar-Villanueva LF, organizador. El estudio de las políticas públicas. México DF: Editorial Porrúa; 1992. p. 197-237.

\section{Mario Hernández}

Facultad de Medicinal Doctorado Interfacultades de Salud Pública, Universidad Nacional de Colombia, Bogotá, Colombia. mehernandeza@unal.edu.co
The political side of relations between scientific knowledge and health policies. Concerning the article by Celia Almeida \& Ernesto Báscolo

The article by Celia Almeida \& Ernesto Báscolo, titled Use of Research Results in Policy DecisionMaking, Formulation, and Implementation: a Review of the Literature, is a stimulus for the debate on relations between science and policy in the contemporary world. A detailed review of the Anglo-Saxon literature allows the authors to present a map of the studies on the use of research results in the policy decision-making process, where they highlight two major trends: a rational and instrumental perspective, underlying the technocratic ideal of achieving "evidence-based policies", and a relational perspective, based on which one understands that research and policymaking processes are essentially different, and that the issue is thus to find the best way for the former to influence the latter, based on strategies that take advantage of "windows of opportunity". The authors take a critical position, according to which, in the analysis of relations between research and health policies, what predominates is an excessive formalization of instruments and pragmatic simplification in the two processes, knowledge production and the policy process in the health field, while calling for more attention to the theme. I share their position and wish to move in this direction, based on an analysis of the political side of the two processes, drawing on other theoretical approaches and developments from the social history of the sciences and the history of health policies and systems 1,2.

To begin, I must say that the political dimension is not exclusive to the public policymaking process. Scientific communities are immersed in power relations that cut across knowledge production. The image of a cycle of scientific knowledge construction spanning from ideas to empirical research and on to innovation and ap- plication, and back to the generation of ideas, is superficial and sadly apolitical, to say the least. Scientific communities are built on power relations, in interdependence with other social power networks ${ }^{3}$, which allows them to achieve greater or lesser centrality, prestige, resources, visibility, and social legitimacy 4 . In the power game, hegemonies are constructed that succeed in occupying a central place in society and the world and that become a reference for policy-making by international and national bureaucracies. Thus, Keynesian economics (in the economic sciences) and health planning (in public health) were the two references for shaping national health systems and services within the framework of expansion of national states from the 1950s to 70s. This predominance has been replaced by neoclassical economics and health microeconomics during the formulation of state and health system reforms in all countries from the 1980s to the present 5,6 . Thus the neoclassical approach to health systems performance assessment conducted by the World Health Organization in its Annual Report 2000, shedding such negative light on the health systems that had not adopted structural reforms from this same neoclassical focus 7 .

Hegemony in scientific communities produces predominant features in the training of both new scientists and professionals. In today's political world, with rare exceptions, the politicians are professionals. And the top and middle managers in the government bureaucracy are also professionals, who promote policies with a specific predominant focus, just as the representatives of political forces or parties in the legislative arena. Therefore, the bureaucracies and politicians frequently share hegemonic views, with minor differences related to the distribution of benefits in the process of formulating a specific policy. This is a second element showing the absence of neutrality in the "evidence" provided by scientific communities. It would be more appropriate to speak of communicating vessels that consolidate hegemonies.

But not everything flows in the same direction. Policy-making itself is a socio-political process featuring various more or less organized actors, and not only professional politicians 8 . These actors not only defend their interests, but also promote more or less formal and explicit views of society and political orientations. In the health field, there are numerous and diverse socio-political actors: health insurance and financial firms, pharmaceutical and biomedical equipment manufacturers, health services providers, health professionals (especially the State medical boards or the equivalent), trade unions, political parties, social and community move- 
ments, and many more. The international and national bureaucracy is both a policy actor and manager, to the extent that the state is both an actor in the political arena and the arena itself 9. The list could go on, but what matters is that each of the socio-political actors uses specific research results differently, from their own vision and cost-benefit assessment, frequently influenced more by media information than by the research results published in scientific journals. The process produces negotiations, strategic alliances, and predominant positions that end up consolidating a certain vision and excluding others. Such that scientists' intended "influence" not only is not neutral, but is also transformed, in turn, by the respective socio-political actors. The communications media (which are also not neutral) play a decisive role in the consolidation of hegemonies.

In short, the pretense of achieving aseptic formulation of "evidence-based policies" does not appear possible, as proposed by the authors. Yet the understanding of the relations between research and health policies cannot overlook the issue of power in the two processes. This subject merits closer and especially less instrumental attention, based on the sociology of power. In this sense the review by Almeida \& Báscolo is highly welcome.
1. Quevedo E, Borda C, Eslava JC, García CM, Guzmán, MP, Mejía P, et al. Café y gusanos, mosquitos y petróleo. El tránsito desde la higiene hacia la medicina tropical y la salud pública en Colombia 1873-1953. Bogotá: Instituto de Salud Pública, Universidad Nacional de Colombia; 2004.

2. Hernández M. La fragmentación de la salud en Colombia y Argentina. Una comparación sociopolítica, 1880-1950. Bogotá: Universidad Nacional de Colombia; 2004.

3. Mann M. Las fuentes del poder social, I. Madrid: Alianza; 1991.

4. Bourdieu P, Chamboredon J-C, Passeron J-C. El oficio de sociólogo. México DF: Siglo XXI Editores; 1975.

5. Hernández M. El proceso sociopolítico de las reformas sanitarias en Colombia. Cartilla de Seguridad Social 1999; 5:21-43.

6. Hernández M. Neoliberalismo en salud: desarrollos, supuestos y alternativas. In: Restrepo DI, editor. La falacia neoliberal. Crítica y alternativas. Bogotá: Universidad Nacional de Colombia; 2002. p. 347-61.

7. Hernández M. El enfoque sociopolítico para el análisis de las reformas sanitarias en América Latina. Rev Fac Nal Salud Pública 2001; 19:57-70.

8. Hernández M. La fragmentación de la salud en Colombia y Argentina: una comparación sociopolítica, 1880-1950. Bogotá: Universidad Nacional de Colombia; 2004.

9. Skocpol T. Bringing the state back in: strategies of analysis in current research. In: Evans P, Rueschmeyer D, Skocpol T, editors. Bringing the state back in. New York: Cambridge University Press; 1999. p. 3-37.
James A. Trostle

Trinity College, Hartford, U.S.A. James.Trostle@trincoll.edu
This is, in general, a nice summation and assessment of the theoretical work being done on the use (and lack of use) of scientific evidence to improve health policy and health systems. However, at times the authors summarized excessively, and at other times they missed opportunities to critically compare the various approaches they reviewed.

For example, the historical growth of political science theorizing was painted too broadly. It is difficult to interpret the conclusion that there was a "confusion between research and the operations approach" that led to a "differentiation (and separation) of functions between scientists and 'consultants"' (is this a critique of the field of operations research? What does it mean to separate scientists from consultants in this way?).

I would have liked to see more explicit and detailed comparisons and evaluations of the formulations of people like Kirkhart or Patton or Forss or Walt \& Gilson. Are they all compatible with one another? If not, which approaches make most sense for which circumstances? Answering these questions would have helped forward the authors' expressed goal of "formulating and developing analytical and explanatory frameworks that perhaps offer more promise...". I also wanted to see more follow-up of the authors' point that in Spanish and Portuguese the same word, "politi$c a$ ", refers both to the content of policy and to the policy-making process itself. What implications might this and other regional differences have for the generalizability in Latin America of research and theorizing based in the United States and Europe?

Whether referring to Northern or Central or Southern America, or elsewhere, I think the authors are quite correct in emphasizing the dynamic and nonlinear relationship between research and policy. It is important that they acknowledge that much of the literature now being generated on evidence-based policy-making has a rather naïve sense of optimism about it, despite warnings decades ago that policy-mak- 